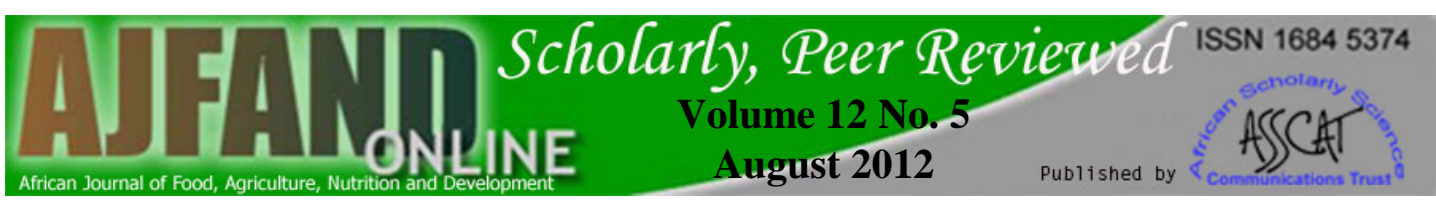

\title{
SPECIES DIVERSITY AND RICHNESS OF WILD BIRDS IN DAGONA- WATERFOWL SANCTUARY, NIGERIA
}

\section{Lameed GA ${ }^{1^{*}}$}

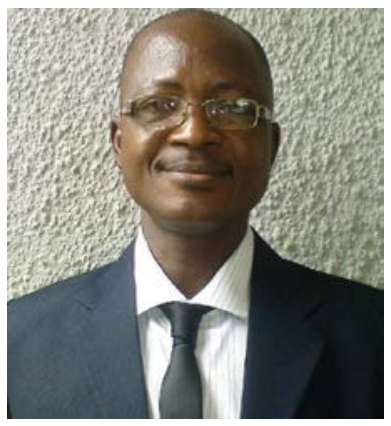

Gbolagade Lameed

*Corresponding author email: lamakim2002@yahoo.com; lamgbola2008@gmail.com ${ }^{1}$ (Associate Professor) Department of Wildlife and Ecotourism Management, Faculty of Agriculture and Forestry, University of Ibadan, Ibadan; Nigeria. 


\section{ABSTRACT}

The study of bird species diversity and richness in Dagona-Waterfowl Sanctuary was carried out during the midst of both early wet and late dry seasons, to provide comprehensive data on wild birds. Dagona Sanctuary is located within the BadeNguru Wetland sector. It is one of the important bird areas marked for the conservation of avifauna species in sub-Sahara region, Nigeria. Line Transect method was used to carry out birds' survey at three different lake sites, namely: Gatsu (site:1), Mariam (site: 2) and Oxbow (site: 3). The instruments used were Garmin ${ }^{\mathrm{TM}} 12$ Global Positioning System (GPS), a pair of binoculars for bird's identification, a field guide test- book and a 1,000 meters tape-rule. The data were tested with the Kolmogorov- Smirnov method o determine distribution level and birds' diversity was assessed using Shannon-Weiner Diversity Index, while parametric tests were applied for all data. The results showed that bird species diversity was normally distributed in all the sites, site 2 had the highest diversity (2.74) compared to site 1: (1.84) and site 3: (1.62). Likewise, bird species richness in the area was normally distributed and significantly different $(\mathrm{P}<0.05)$ among the three sites. Site 1 had the highest number of bird species richness (16.36) (Species diversity is different species of birds at the site, while species richness is referring to specific species population), compared to site 2: (14.32) and site 3: (11.51). It was observed that there is a significant relationship between vegetation density and bird species diversity, because as tree density increases, diversity of bird species decreases. Therefore, there is a significant relationship between vegetation density and bird species diversity. A total of 135 bird species in 40 families was recorded during the survey. Seventy-four percent were found in site1, sixty-three percent in site 2 and seventy-one percent in site 3 . The majority of wetland birds observed during this study were resident (Ardeidae family), migratory (Accipitridae family) and palearctic species (Yellow Wagtail, Warblers, Northern Shoveler and Sandpipers). It can be concluded that wild birds are good indicators of environmental condition, revealing the state of the wetland. Some sites were more disturbed, as observed in site 1 and site 3 . It was, however, recommended that regular monitoring of the sites should be carried out so as to control changes in the state of the wetland ecosystem.

Key words: Wetland, birds, diversity, richness, vegetation 


\section{INTRODUCTION}

Wetlands are of important ecological significance in the tropical region, which serves as a major link between the natural resource management and agricultural practices. They are a store house or hot-spot for the conservation of important species that rural inhabitants mostly depend upon for a source of protein, while at the same time serving deep interests of the conservationists for protection. In all the three types of wetlands (marine/coastal, inland or man-made), the most significant point of reference is water management. Therefore, a wetland or riparian ecosystem is a servicing point for diverse species of animals (fishes, birds, antelopes, primates and carnivores) that need water either for drinking, wallowing or abode [1].

Wetlands are unique biotic communities involving diverse plants and animals that are adapted to shallow and often dynamic water regimes. The Convention on Wetlands of International Importance, commonly called the "Convention on Wetlands" (or the RAMSAR convention), signed in Ramsar, Iran in 1971, defines wetlands as "areas of marsh, fern, peat land or water, whether natural or artificial, temporary or permanent, with water that is static or flowing, fresh, brackish or salt, including areas of marine water, the depth of which at low tide does not exceed six meters". In addition, the Convention provides that wetlands "may incorporate riparian and coastal zones adjacent to the wetlands and islands or bodies of marine water deeper than six meters at low tide lying within the wetland" [1]. There are also man-made wetlands such as fish and shrimp ponds, farm ponds, irrigated agricultural land, salt pans, reservoirs, gravel pits, sewage pits, sewage farms, and canals [2].

Although wetlands occupy a small portion of the earth's land area, they are very important in the biosphere. Over geologic time, wetland environments produced the vegetation that has been converted into coal. Salt water marshes are important breeding areas for many oceanic animals and many invertebrates. Dominant animal species in fresh water wetlands include many species of insects, birds, and amphibians; few mammals are also included this biome [3].

Wetlands are known for their abundance of birds. The use of wetlands and their resources is widespread among many diverse bird taxa of the world. Avian adaptation to utilize wetlands and other aquatic systems are diverse and include anatomical, morphological, behavioral changes. Anatomically, they include designs for diving and swimming, such as body compression to increase gravity, or adaptation for plunge diving from great heights [4]. Respiratory physiology differs dramatically in those bird species that engage in long period of time deep diving into the water body [5]. Morphological adaptations include bills that strain, peck, spear, store and grab, and feet that allow swimming, diving, walking on mudflat, wadding or grabbing and holding fish. Not only do body parts differ in general form, but also size of bills, legs, and flight patterns differ across a gradient of wetland edges [6]. As a result of these adaptations, birds are better equipped as a group to exploit wetland resources and are often used as indicators of conditions within a wetland ecosystem [4]. 
In Nigeria, the Hadeija-Nguru Lake (Marma channel) complex is a designated Ramsar site. The surface area enclosed is about 58,100 hectares, with an elevation of 340$345 \mathrm{~m}$, located northeastern Nigeria $\left(10^{\circ} 22^{\prime} \mathrm{N}, 012^{\circ} 46^{\prime} \mathrm{E}\right)$, with two-third of this site in Jigawa State and one-third in Yobe State. The Nguru Lake is a good representation of a natural or near-natural wetland, which embodies all the diverse flora and fauna of both the Sahel and the Sudan savanna in a single limited location. It regularly supports more than 20,000 water birds and is also a wintering ground for many palearctic migrant birds. A total of 377 wetland bird species have been recorded in the wetland and the total numbers of water birds recorded during the January African Water bird census counts were 259,769 in 1995; 201,133 in 1996 and 324,510 in 1997 [7]. The aim of this study was to assess species diversity and richness of wild birds and to provide a species list in Dagona Waterfowl Sanctuary. Birds are good environmental indicators, revealing the state of the ecosystems such as wetland. They also serve as dispersal agents in transferring nutrients and spores from one place to another during their migration and local movements [4].

\section{THE STUDY AREA}

The Dagona Wildlife Sanctuary is located within the Bade-Nguru Wetland Sector. The Sanctuary covers an area of 938sq.km and comprises the 1966 legislated Bade Native Authority Gogoram and Zurgum Baderi Forest Reserves. It is situated southwest of Bade and Jakusko local government areas of Yobe State. It is located between latitudes $12^{\circ} 13^{\prime}$ and $13^{\circ} 00^{\prime}$ and longitudes $10^{\circ} 00^{\prime}$ and $11^{\circ} 00^{\prime}$ (Figure 1 - Map of Nigeria showing location of the Sectors). Dagona Waterfowl Sanctuary is significant to the internationally assisted conservation effort to protect the palaearctic migrant birds. It is open Sudan/scrub Sahelian vegetation, though a small part of the wetland is covered with water all year round yielding support for water birds and other wildlife found in that area.

The sanctuary is bordered by some villages and the main occupation is pastoral farming with high incidence of grazing by the Fulani community. The Waterfowl sanctuary is among the Hadeija-Nguru Wetlands while the management of the sanctuary is under the jurisdiction of the Chad Basin National Park. The sanctuary is under multiple-use management, and there is no free access to wild resources (wild animals, fish, birds). However, grazing and collection of wild resources are practiced by the local population illegally, and there is, therefore, need for more strict enforcement of laws [8]. 


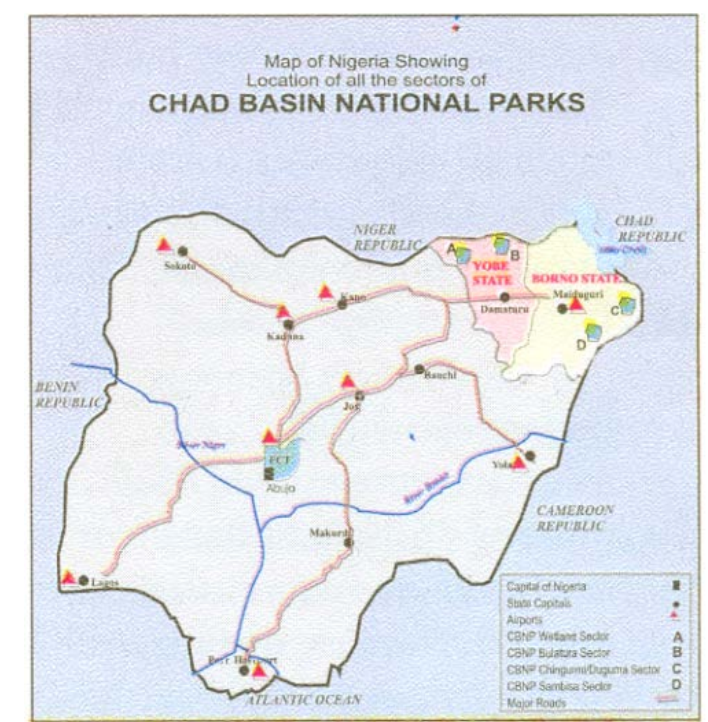

Figure 1: Map of Nigeria showing location of all sectors of Chad Basin National Park.

\section{MATERIALS AND METHODS}

The Line Transect method was used to survey birds. This method proved most efficient in terms of data collection per unit effort. This census involves an observer moving slowly along the routes and recording all birds detected on either side of the route. The length of transects depends on the type of survey but is usually constrained by accessibility and thus may not be fixed. Line transects are often used to collect data in large open areas and is more efficient than point counts as one tends to record more birds per unit time [9].

Surveys were carried out at three different lakes (Gatsu, Mariam and Oxbow, referred to as sites 1 to 3) in 2009 using the line transect method. A Garmin ${ }^{\mathrm{TM}} 12$ Geographic Positioning System (GSP) was used to mark each point. At each site, bird observation was carried out twice daily. Morning between 0630hrs and 1000hrs and evening, between $1600 \mathrm{hrs}$ and $1800 \mathrm{hrs}$ by walking slowly along transects and making observations. The length of each transect was one kilometer and was subdivided into 50meters sub-sections to aid data collection and habitat measurements. At each site, transects were placed $100 \mathrm{~m}$ apart.

Birds were counted as bird seen and heard and birds in flight were also recorded. A pair of binoculars with magnification 7 x 50 was used in identification of birds visually alongside a field guide [1].

The data were tested with the Kolmogorov- Smirnov to determine whether or not they were normally distributed while parametric tests were applied for all data. 
Birds’ diversity was calculated using the Shannon-Weiner Diversity Index, H

$$
H=-\sum_{i=1}^{S} P_{i} \ln P_{i}
$$

$\mathrm{P}_{\mathrm{i}}=$ Proportion of individual species

$\mathrm{S}=$ Total number of species of the community (number of bird seen and heard).

Average bird diversity was calculated by getting a mean of the replicated surveys of bird diversity at each point for mornings and evenings for all sites. One-way ANOVA was used to determine if the differences in mean bird species diversity across sites were significant. A post hoc test was carried out to ascertain the level of variance in bird species diversity at the three sites.

The means of vegetation variables were calculated. Pearson's correlation was used to determine if there were significant associations between habitat variables and mean bird diversity. Using the bird diversity as the dependent variable, the Generalized Linear Model (GLM) was used to test if vegetation variables had any relationship with bird diversity.

Model equation is given as:

$$
\begin{aligned}
& \mathrm{Y}=\mathrm{b}_{0}+\mathrm{b}_{1} \mathrm{x} \\
& \text { Where } \mathrm{Y}=\text { dependent variable } \\
& \mathrm{b}_{0}=\text { corrected } \mathrm{R}^{2}, \mathrm{~b}_{1}=\text { independent variables and } \mathrm{x}=\text { error }
\end{aligned}
$$

\section{RESULTS}

\section{Species Diversity}

The results of this study showed that bird species diversity was normally distributed at all the sites (Table 2). A one-way ANOVA showed that bird diversity varied significantly $(\mathrm{P}<0.05)$ between the three sites. Site 2 (Maram) had the highest diversity (2.74) compared to site 1 (Gastu) (1.84) and site 3 (Oxbow) (1.62). Thus, site 2 had the highest diversity as indicated in Figure 2. Birds were more easily sighted and species easily identified; they were concentrated in the woodland forest ecosystem than in the riparian environment. 


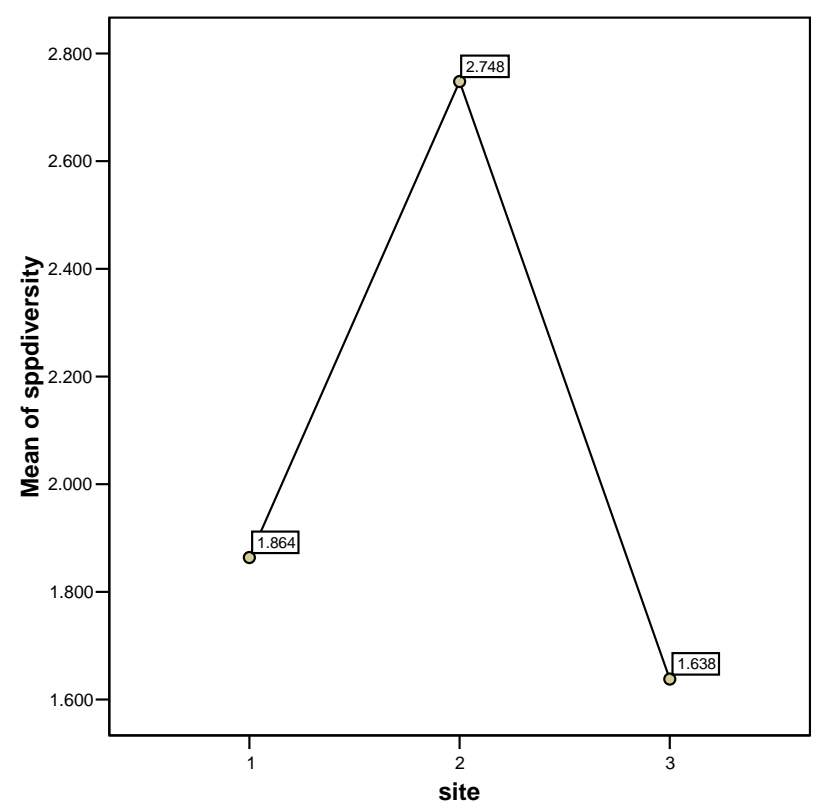

Figure 2: Bird species diversity in each site

\section{Species Richness}

Bird species richness in the area was normally distributed among the three sites, (Table 3). There was a significant difference $(\mathrm{P}<0.05)$ within species richness at the three sites (Table 4). Site 1 had the highest species richness (16.36) compared to the other two sites 2 and 3 that gave 14.32 and 11.51 respectively.

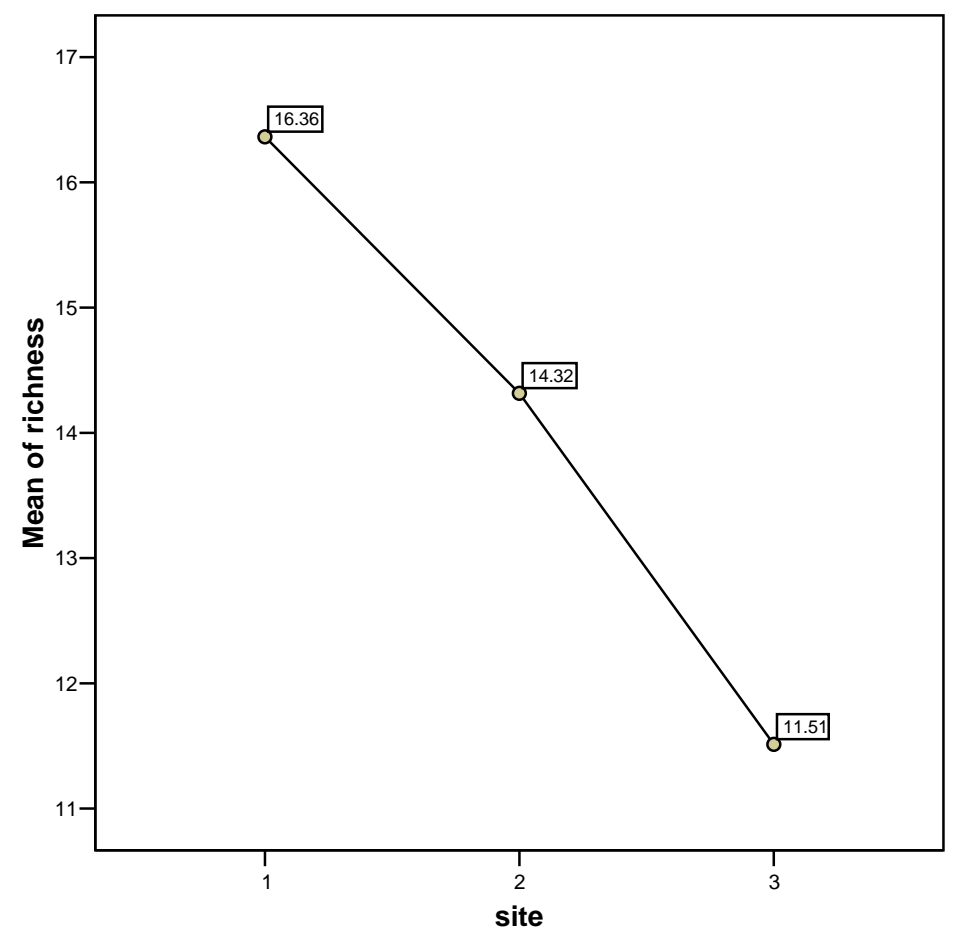

Figure 3: Mean species richness of the three sites 
Figure 3 showed that site 1(Gastu lake) had the highest number of bird species (16.36) as compared to site 2 (Maram lake) (14.32) and site 3(Oxbow lake) (11.51); site 3 had the least number of bird species.

\section{Vegetation Distribution \& Species Diversity}

There was a significant relationship between vegetation densities and bird species diversity. As tree density increased, diversity of bird species decreasesd (figure 4). At tree density of 1.0 the bird species diversity recorded at evening was above 4,000; at 2.0 tree density the diversity of bird species was 2,500. It was noted that there was more human disturbance (anthropogenic activity) at the forested area of the lakes. Activities like firewood extraction collection, poaching, bush burning and forest fruit gathering were common. Likewise, more birds were recorded at evening time $(>4,000$ birds) than during the morning time (3,000 birds) within the vegetation area. This indicated greater bird activities at evening time before nest-roosting than earlymorning hours' activity.
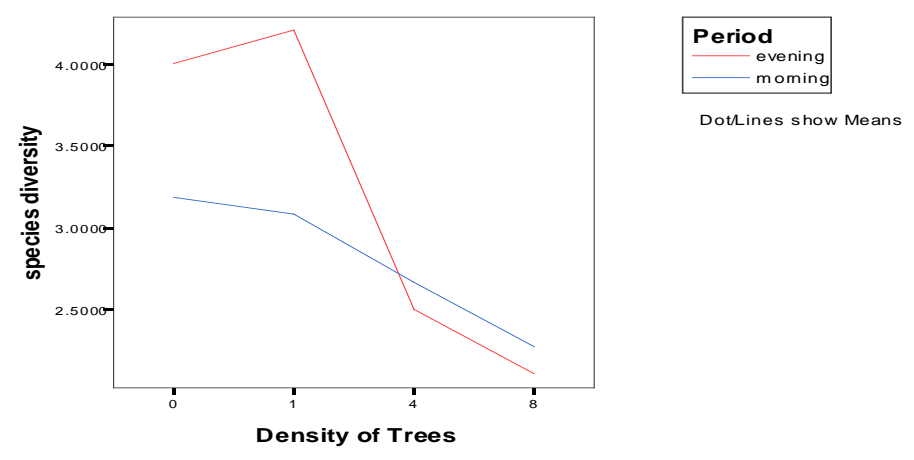

Figure 4: Relationship of tree density and bird species diversity

\section{Checklist of Bird species in Dagona Waterfowl Sanctuary}

A total of 135 bird species in 40 families were recorded during the survey (Table 5). Seventy-four percent were found in Gastu Lake, sixty-three percent in Maram Lake and seventy-one percent in Oxbow Lake. More bird species were recorded at disturbed areas (site 1) compared to least disturbed sites (2 and 3).

\section{DISCUSSION}

The majority of wetland birds observed during this study were resident species, migratory and palearctic bird species. Some of the palearctic species recorded included the Yellow Wagtail, the Warblers, Northern Shoveler, the Sandpipers and the migrants and residents were also of a considerable number. The species that were winter migrants used the wetlands area for resting and other activities while waiting for favorable condition in their home range. During this time, they store enough fat for the journey back to Europe [10]. Migrant species observed during the study were fairly few, especially the Family Accipitridae which were observed to have moved 
down South. The period of the study favoured the level of water that is deep enough for wetland birds, especially the water birds to carry out daily activities such as feeding, resting, nesting and predator escape. An important observation is that the bird diversity and abundance (richness) varies across sites and this was influenced by various factors, some of which included: the fact that wetlands provide food for birds in form of plants, vertebrates and invertebrates. Some of them forage for food in wetland soil, some in the water column, and others use the dry landscape, along the streams. They may be affected by quality and quantity of food. Vegetarian birds (follivore) like the White-Faced Whistling duck are likely to be affected by quality of the vegetation as it was observed during this study. Birds that are commonly found at the riparian vegetation need more protein, less of other tannins and poisonous substances which are required by the carnivorous birds such as the herons and the storks. This is because it is the quality of food which is important to the species but not the quantity [11].

The extent to which wetland birds utilize wetland as cover and hiding areas depends and varies among wetland birds; the absence of such hiding cover may result in some species being scarce. Well vegetated wetlands seem attractive to wetland bird species [12].

The absence of a specific and proper nesting site may affect the abundance and diversity of wetland bird species. Ducks nest over the water, while the Spur-winged Goose nests on the sand bars as observed during the study, the Spur-winged Lapwing are on the lake shore as shore feeder. The Jacanas were observed in the vegetated part of the lake at the three sites and so were the lily trotters. The bird species found in wetlands need specific areas to carry out reproductive activities such as roosting and nesting [13].

This study revealed a positive relationship between percentage ground cover, shrub density and tree density to bird recorded. More birds were observed in areas with higher percentage of ground cover (disturbed sites) and shrub density (135 bird species) but fewer birds were observed as tree density increased (71 bird species). This observation indicated that some wetland birds used the trees as roosting site. This was observed with some species such as the Egrets, Ibises, Herons and Storks. These species were found during the survey on the bare ground feeding on the mudflats fish and other vertebrate. Thus, habitat has long been used as a predictor of bird species abundance, and each variety of birds has developed different preferences for habitat [14]. Birds select vegetation variables according to the manner by which an individual habitat affects access to food, mates or its vulnerability to predators [15].

\section{CONCLUSSION}

Bird communities are often referred to as an ideal indicator to monitor the ecological condition of any wetlands as they impact on all the trophic levels of an aquatic ecosystem. Dagona Waterfowl Sanctuary is a peculiar example of these bird communities. Aquatic ecosystems have significant impact on migratory birds. Birds carry out diverse ranges of ecological functions among vertebrates. As consumers,

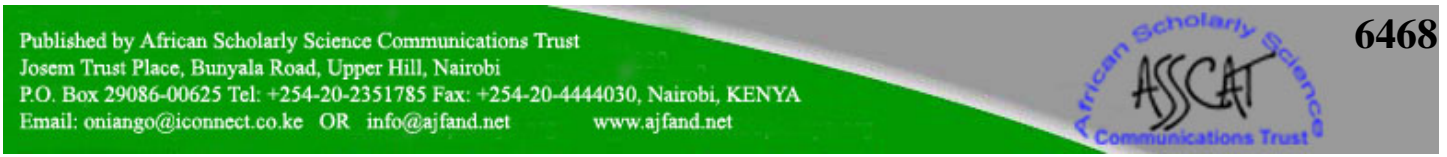


they help regulate populations of smaller animals they prey upon, disperse plant seeds, and pollinate flowering plants. As prey items, birds and bird eggs are consumed by a variety of larger predators. Birds also benefit humans by providing important ecosystem services such as regulating services by scavenging carcasses and waste, by controlling population of invertebrates and vertebrate pests, by pollinating and dispersing the seeds of plants; and supporting services by cycling nutrients. They served as indicators revealing the state of the wetland, as dispersal agents in transferring nutrients and spores from one wetland to another during migration and local movements [16].

Grazing, fishing and logging were the main illegal activities in the Dagona Waterfowl Sanctuary and this might be detrimental to bird species diversity in the long term. Fulani cattle grazers mostly invade the Sanctuary and fell trees to get leaves for their cattle. Several attempts by the authorities to curtail these activities were abortive. Studies have shown that selective logging can affect the diversity of bird species positively [17]. This can be introduced in some parts of the sanctuary that are experiencing fewer disturbances of bird species at sustainable management level.

Bird diversity and abundance are normally distributed among the sites in Dagona Waterfowl Sanctuary and some species are more abundant than others. This is due to the fact that some parts were more disturbed than others as it was observed that Gastu and Oxbow lakes had more disturbance than the Maram lakes. Also, the communities around the Gastu and Oxbow lakes were more than those of Maram, which means reduced human disturbance on the habitat and the bird communities. A check-list of 135 avian composition was generated and it was found that habitat structure affects avian diversity and the species abundance in this study. Therefore, it was recommended that regular monitoring of the site should be carried out so as to control changes in the state of wetland especially on the resident and palearctic species. Thus, protection of this ecosystem (Dagona wetland Sanctuary) will ensure better protection of resource richness (water, soil, animals and plants) and thereby enable future sustainable utilization of the resources. If this ecosystem is under threat by humans and is not properly managed by policy makers, then it will send a serious signal on environmental viability of the region and invariably affect the general ecosystem productivity. 


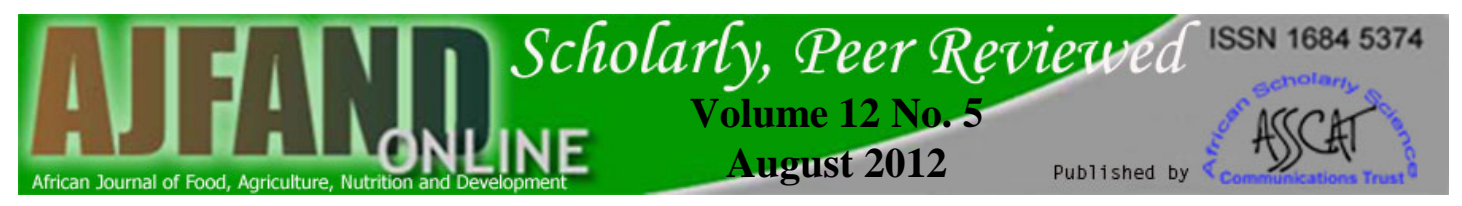

Table 1: One-Sample Kolmogorov Smirnov Test for species diversity of the sites

\begin{tabular}{lcccccc}
\hline Site & \multicolumn{2}{c}{ Morning } & \multicolumn{2}{c}{ Evening } & \multicolumn{2}{c}{ Sig. } \\
\multicolumn{2}{c}{ Z-score } & $\mathrm{N}$ & \multicolumn{2}{c}{0.9992} \\
Gastu & 0.6726 & 0.3680 & 18 & 2 & 0.7562 & 0.9992 \\
Maram & 0.52185 & 0.5928 & 10 & 10 & 0.8737 & 0.9482 \\
Oxbow & 0.5558 & 0.9047 & 33 & 15 & 0.9168 & 0.3862 \\
\hline
\end{tabular}

Table 2: Least Significant Difference for Multiple Comparisons of Species Diversity (Dependent Variable)

\begin{tabular}{|c|c|c|c|c|c|c|}
\hline \multirow{4}{*}{ (I) site } & \multirow{4}{*}{ (J) site } & \multirow{4}{*}{$\begin{array}{l}\text { Mean Difference } \\
(\mathrm{I}-\mathrm{J})\end{array}$} & \multirow{4}{*}{$\begin{array}{l}\text { Std. } \\
\text { Error }\end{array}$} & \multirow{4}{*}{ Sig. } & $95 \%$ & Confidence \\
\hline & & & & & Interval & \\
\hline & & & & & Lower & Upper \\
\hline & & & & & Bound & Bound \\
\hline \multirow[t]{2}{*}{1} & 2 & -0.88419 & 0.173621 & $<0.0001$ & -1.22711 & -0.54128 \\
\hline & 3 & 0.22575 & 0.135651 & 0.098056 & -0.04217 & 0.493673 \\
\hline \multirow[t]{2}{*}{2} & 1 & 0.884193 & 0.173621 & $<0.0001$ & 0.541275 & 1.22711 \\
\hline & 3 & 1.109942 & 0.155255 & 3.05E-11 & 0.803299 & 1.416585 \\
\hline \multirow[t]{2}{*}{3} & 1 & -0.22575 & 0.135651 & 0.098056 & -0.49367 & 0.042174 \\
\hline & 2 & -1.10994 & 0.155255 & $<0.0001$ & -1.41659 & -0.8033 \\
\hline
\end{tabular}

Table 3: One-Sample Kolmogorov Smirnov Test for bird species richness in each site

\begin{tabular}{|c|c|c|c|c|c|}
\hline \multirow[b]{3}{*}{ Gastu } & \multicolumn{5}{|c|}{ Evening } \\
\hline & \multicolumn{2}{|c|}{ Z-score } & \multicolumn{2}{|l|}{$\mathrm{N}$} & Sig. \\
\hline & 1.049485 & 0.368049 & 2 & 18 & $\begin{array}{ll}0.22 & 0.99\end{array}$ \\
\hline Maram & 0.550998 & 0.654709 & 10 & 10 & $0.92 \quad 0.78$ \\
\hline Oxbow & 1.869643 & 0.810866 & 15 & 33 & $\begin{array}{ll}0.00 & 0.53\end{array}$ \\
\hline
\end{tabular}


Table 4: Least Significant Difference for Multiple Comparisons of Species Richness (Dependent Variable)

\begin{tabular}{|c|c|c|c|c|c|c|}
\hline (I) site & (J) site & $\begin{array}{l}\text { Mean Difference } \\
(\mathrm{I}-\mathrm{J})\end{array}$ & Std. Error & Sig. & \multicolumn{2}{|c|}{ 95\% Confidence Interval } \\
\hline \multirow{4}{*}{1} & & & & & Lower & Upper \\
\hline & & & & & Bound & Bound \\
\hline & 2 & 2.047969481 & 2.503185 & 0.414506 & -2.89605 & 6.99199 \\
\hline & 3 & 4.850705329 & 1.955752 & 0.014178 & 0.987916 & 8.713495 \\
\hline \multirow[t]{2}{*}{2} & 1 & -2.047969481 & 2.503185 & 0.414506 & -6.99199 & 2.896051 \\
\hline & 3 & 2.802735848 & 2.238395 & 0.212377 & -1.6183 & 7.223772 \\
\hline \multirow[t]{2}{*}{3} & 1 & -4.850705329 & 1.955752 & 0.014178 & -8.71349 & -0.98792 \\
\hline & 2 & -2.802735848 & 2.238395 & 0.212377 & -7.22377 & 1.6183 \\
\hline
\end{tabular}


Table 5: Checklist of Bird species in Dagona Waterfowl Sanctuary

\begin{tabular}{|c|c|c|}
\hline Family & Scientific name & Common name \\
\hline \multirow[t]{10}{*}{ 1. Accipitridae } & Accipiter tachiro & African goshawk \\
\hline & Circus ranivorus & African marsh harrier \\
\hline & Accipitridae & Bird of prey \\
\hline & Elanus caeruleus & Black-shouldered kite \\
\hline & Melierax metabates & Dark chanting goshawk \\
\hline & Kaupifalco monogrammicus & Lizard buzzard \\
\hline & Circus ranivorus & Marsh harrier \\
\hline & Accipiter ovampensis & Ovambo sparrowhawk \\
\hline & Circus macrourus & Pallid harrier \\
\hline & Acccipiter badius & Shikra \\
\hline \multirow[t]{3}{*}{ 2. Alcedinidae } & Ceyx lecontei & African dwarf kingfisher \\
\hline & Halcyon leucocephala & Grey-headed kingfisher \\
\hline & Ceryle rudis & Pied kingfisher \\
\hline \multirow[t]{9}{*}{ 3. Ardeidae } & Egretta ardesiaca & Black heron \\
\hline & Bubulcus ibis & Cattle egret \\
\hline & Egretta alba & Great egret \\
\hline & Ardea cinerea & Grey heron \\
\hline & Egretta intermedia & Intermediate egret \\
\hline & Egretta garzetta & Little egret \\
\hline & Egretta garzetta & Lesser egret \\
\hline & Ardea purpurea & Purple heron \\
\hline & Ardeola ralloides & Squacco heron \\
\hline \multirow[t]{5}{*}{ 4. Anatidae } & Dendrocygna viduata & White-faced whistling duck \\
\hline & Anas querquedula & Garganey \\
\hline & Sarkidiornis melanotos & Knob-billed duck \\
\hline & Anas clypeata & Northern shoveler \\
\hline & Plectropterus gambensis & Spur-winged goose \\
\hline
\end{tabular}




\begin{tabular}{|c|c|c|}
\hline Family & Scientific name & Common name \\
\hline \multirow[t]{4}{*}{ 5. Alaudidae } & Galerida modesta & Sun lark \\
\hline & Eremopterix nigriceps & Black-crowned sparrow lark \\
\hline & Eremopterix leucotis & Chestnut-backed sparrow lark \\
\hline & Galerida cristata & Crested lark \\
\hline \multirow[t]{2}{*}{ 6. Bucerotidae } & Tokus camurus & Red-billed hornbill \\
\hline & Tokus nasutus & African grey hornbill \\
\hline \multirow[t]{9}{*}{ 7. Columbidae } & Streptopelia hypopyrrha & African collared dove \\
\hline & Streptopelia decipiens & African mourning dove \\
\hline & Turtur abyssinicus & Black-billed wood dove \\
\hline & Streptopelia spp & Dove \\
\hline & Streptopelia sensgalensis & Laughing dove \\
\hline & Oena capensis & Namaqua dove \\
\hline & Streptopelia vinacea & Vinaceous dove \\
\hline & Streptopelia semitorquata & Red-eyed dove \\
\hline & Columba guinea & Speckled pigeon \\
\hline \multirow[t]{4}{*}{ 8. Ciconiidae } & Anastomus lamelligerus & African openbill stork \\
\hline & Ciconia nigra & Black stork \\
\hline & Leptoptilos crumeniferus & Marabou stork \\
\hline & Anastomus lamelligerus & Open-bill stork \\
\hline 9. Collidae & Urocolius macrourus & Blue-naped mousebird \\
\hline 10. Corvidae & Corvus albus & Pied crow \\
\hline 11. Coraciidae & Coracias abbyssinicus & Abyssian rollerS \\
\hline \multirow[t]{2}{*}{ 12. Capitonidae } & Pogoniulus scolopaceus & Yellow-fronted tinkerbird \\
\hline & Lybius vieilloti & Veillot barbet \\
\hline \multirow[t]{2}{*}{ 13. Charadriidae } & Charadrius marginatus & White-fronted plover \\
\hline & Vanellus spinosus & Spur-winged lapwing \\
\hline 14. Cuculidae & Centropus sensgalensis & Senegal coucal \\
\hline
\end{tabular}




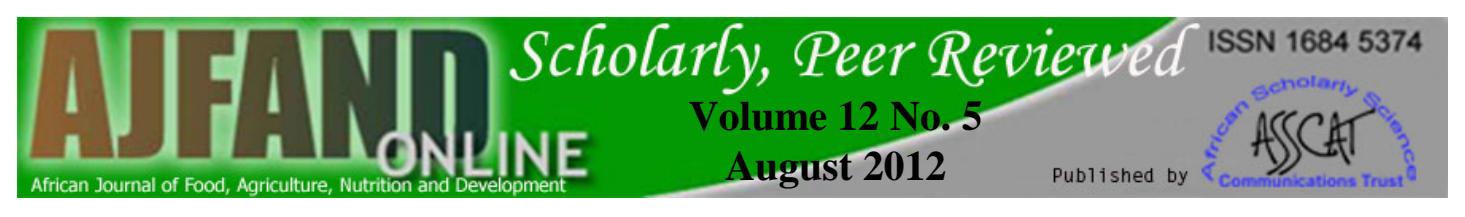

\begin{tabular}{|c|c|c|}
\hline Family & Scientific name & Common name \\
\hline \multirow[t]{7}{*}{ 15. Estrildidae } & Euodice cantans & African silverbill \\
\hline & Estrilda troglodytes & Black rumped waxbill \\
\hline & Amadina fasciatus & Cut-throat \\
\hline & Lagonosticta Senegal & Red-billed firefinch \\
\hline & Estrilda troglodytes & Black-rumped waxbill \\
\hline & Uraeginthus bengalus & Red-cheeked cordon bleu \\
\hline & Serinus leucopygius & White rumped seedeater \\
\hline 16. Falconidae & Falco ardosiaceus & Grey kestrel \\
\hline 17. Jacanidae & $\begin{array}{l}\text { Actophilornis Africana } \\
\text { Microparra capensis }\end{array}$ & $\begin{array}{l}\text { African jacana } \\
\text { Lesser jacana }\end{array}$ \\
\hline 18. Laniidae & Lanius meridionalis & Southern grey Shrike \\
\hline 19. Malaconotidae & Laniaruus barbarous & Yellow-crowned gonolek \\
\hline \multirow[t]{2}{*}{ 20. Motacillidae } & Motacilla flava & Yellow wagtail \\
\hline & Motacilla flava & Common wagtail \\
\hline \multirow[t]{2}{*}{ 21. Meropidae } & Merops pusillus & Little bee-eater \\
\hline & Merops orientalis & Little green bee-eater \\
\hline \multirow[t]{2}{*}{ 22. Musophagidae } & Crinifer piscator & Western grey plantain-eater \\
\hline & Crinifer piscator & Plantain eater \\
\hline \multirow[t]{2}{*}{ 23. Nectariniidae } & Cinnyris pulchellus & Beautiful sunbird \\
\hline & Hedydipna platura & Pygmy sunbird \\
\hline \multirow[t]{11}{*}{ 24. Ploceidae } & Ploceus spp & Weavers \\
\hline & Bubalornis albirostris & Buffalo weaver \\
\hline & Plcepasser superciliosus & Chestut-crowned sparrow weaver \\
\hline & Anomalospiza imberbis & Cuckoo finch \\
\hline & Quelea quelea & Red-billed quelea \\
\hline & Ploceidae & Bishop \\
\hline & Ploceus luteolus & Little weaver \\
\hline & Anaplectes rubriceps & Red-headed quelea \\
\hline & Ploceus cucullatus & Village weavers \\
\hline & Sporopipes frontalis & Speckle-fronted weaver \\
\hline & Ploceus vitellinuus & Vitelline masked weaver \\
\hline
\end{tabular}




\begin{tabular}{|c|c|c|}
\hline Family & Scientific name & Common name \\
\hline \multirow[t]{3}{*}{ 25. Passeridae } & Passer luteus & Sudan golden sparrow \\
\hline & Petronia dentate & Bush petronia \\
\hline & Passer griseus & Northern grey-headed sparrow \\
\hline \multirow[t]{2}{*}{ 26. Phasianidae } & Ptilopachus petroosus & Stone partridge \\
\hline & Francolinus clappertoni & Clapperton's francolin \\
\hline 27. Phalacrocoracidae & Phalacrocorax africanus & Long-tailed comorant \\
\hline 28. Picidae & Dendropicos goertae & Grey woodpecker \\
\hline \multirow[t]{2}{*}{ 29. Psittacidae } & Psittacula krameri & Rose-ringed parakeet \\
\hline & Poicephalus sensgalus & Senegal parrot \\
\hline 30. Phoeniculidae & Phoeniculus purpureus & Green woodhoopoe \\
\hline 31. Pycnonotidae & Pycnonotus barbatus & Common bulbul \\
\hline 32. Recurvirostridae & Himantopus himantopus & Black-winged stilt \\
\hline \multirow[t]{3}{*}{ 33. Sturnidae } & Lamprotornis pulcher & Chestnut-bellied starling \\
\hline & Lamprotornis purpureus & Purple glossy starling \\
\hline & Lamprotornis caudatus & Long-tailed starling \\
\hline \multirow[t]{4}{*}{ 34. Scolopacidae } & Actitis hypoleucos & Common sandpiper \\
\hline & Calidris minuta & Little stint \\
\hline & Philomachus pugnax & Ruff \\
\hline & Tringa glareola & Wood sandpiper \\
\hline \multirow[t]{8}{*}{ 35. Sylviidae } & Sylvia communis & Common whitethroat \\
\hline & Sylvia curruca & Lesser whitethroat \\
\hline & Hippolias polyglotta & Melodious warbler \\
\hline & Sylvietta brachyuran & Northern combrec \\
\hline & Hippolais spp & Sedge wabler \\
\hline & Acrocephalus schoenobaenus & Tawny-flanked prinia \\
\hline & Prinia subflava & Warbler \\
\hline & Sylvia spp & Willow warbler \\
\hline \multirow[t]{2}{*}{ 36. Threskiornithidae } & Plegadis falcinellus & Gossy ibis \\
\hline & Threskiornis aethiopica & Sacred ibis \\
\hline
\end{tabular}




\begin{tabular}{lll}
\hline Family & Scientific name & Common name \\
\hline 37. Timaliidae & Turdoides plebejus & Brown babblers \\
38. Turdidae & Cercotrichas podobe & Black scrub robin \\
& Myrmecocichla aethiops & Northern anteater chat \\
39. Upupidae & Upupa epops & Hoopoe \\
40. Viduidae & Vidua macroura & Pin-tailed whydah \\
& Vidua orientalis & Sahel paradise whydah \\
& Vidua chalybeate & Village indigobird \\
& Euplectes spp & Widow bird
\end{tabular}




\section{REFERENCES}

1. Ramsar Convention Bureau: Background papers on Wetland values and Function. Gland, Switzerland: Ramsar convention Bureau, http://www.ramsar.org/info/values, 2000. (accessed in August 2011).

2. Ramsar Convention Bureau: What is Ramsar convention on Wetlands? Gland, Switzerland: Ramsar Convention Bureau. 2002.

3. Rana SVS Essentials of ecology and environmental sciences. Chaudhary Charan Singh University, Prentice- Hall of India, New Delhi-110001. 2005.

4. Niemi GJ Patterns of morphological evolution in bird genera of New World and Old World Peatland. Ecology 66, 1215-28. 1985.

5. Ezealor AU Hadejia-Nguru Wetlands. Critical Sites for Biodiversity Conservation in Nigeria, Nigerian Conservation Foundation, Lagos. pp 66-68. 2002.

6. Ezealor AU Nigeria: Important Bird Areas in Africa and associated islands: priority sites for Conservation. BirdLife Conservation series No.11. pp 673682 in L.D.C and M.L. Evans, eds. Newbury, U.K.: Pisces publications. 2001.

7. Bibby CJ, Burgess N and DA Hill Bird Census Techniques. Academic Press, London. 2000.

8. Borrow $\mathbf{N}$ and $\mathbf{R}$ Demey Birds of Western Africa. Christopher Helm, London. 2001.

9. Yallop ML, Connell MJ and R Bullock Waterbirds Herbivory on a newly created wetland complex: Potential implication for site management and habitat creation. Wetland ecology and management 12:395-408. 2003.

10. Manu SA Effects of habitat fragmentation on the distribution of forest birds in south western Nigeria with particular reference to the Ibadan Malimbes and other Malimbes, PhD thesis. University of Oxford. 2000.

11. Cody ML An introduction in habitat selection in birds. In Habitat selection in birds (Cody ed.) Academic Press Inc. London pp 191-248. 1985.

12. Weins JA The Ecology of Bird Communities. Foundations and patterns Cambridge University Press, Cambridge. Vol 1. Cambridge University press. Pp 539. 1997.

13. Hansen AJ, Knight RL and JM Marzluff Effects of exurban development on biodiversity: patterns, mechanism and research needs. Ecological Application vol.15 pp1893-1905. 2005. 
14. Huston MA Biological Diversity. Cambridge University Press, Cambridge. 1994.

15. Manu SA Effects of habitat fragmentation on the distribution of forest birds in South Western Nigeria with particular reference to the Ibadan Malimbes and other Malimbes, PhD thesis. University of Oxford. 2000.

16. Boecklen WJ Conservation status of insects: mass extinction, scientific interest, and statutory protection. Entomology serving society: emerging technologies and challenges (ed.by S.B Vinson and R.L Metcalf) pp 40 - 57. Entomological society of Africa, Lanham, Maryland. 1991.

17. Birdlife International. Threatened Birds of the World. BirdLife International, Cambridge. $2^{\text {nd }}$ Edition, 2000. 